Key words military education, training of military personnel, higher education institutions, military institutions of higher education, educational process in military institutions of higher education, Ukraine.

удк 378.011.3-051:004.738.5(043.3)

Володимир Шевченко

Національний педагогічний

університет імені М. П. Драгоманова

ORCID ID 0000-0002-8905-5483

DOI 10.24139/2312-5993/2020.02/205-215

\title{
ПСИХОЛОГО-ПЕДАГОГІЧНІ ОСОБЛИВОСТІ ВИКОРИСТАННЯ КОМП'ЮТЕРНО-ОРІЕНТОВАНИХ СИСТЕМ НАВЧАННЯ ОХОРОНИ ПРАЦІ
}

Сьогодні більшість освітніх установ зіштовхуються з організаційними, технічними й матеріальними труднощами під час організації навчання у сфері апаратного і програмного забезпечення комп'ютера на реальному устаткуванні зі встановленим на ньому програмним забезпеченням (ПЗ), експериментування з яким може призвести до збоїв або тимчасового припинення функкціонування устаткування. Часто під час проведення практичного заняття немає можливості виділити студентам комп'ютери для вивчення апаратних засобів, установки налаштування і тестування ПЗ конкретною групою студентів; у більшості випадків під час установки й налаштування Пз необхідною $\epsilon$ наявність повноважень адміністратора, які не надаються студентам, виходячи з необхідності забезпечення безпеки комп'ютерів та інформаційної мережі освітньої установи; установка і налаштування деякого ПЗ тривала в часовому проміжку операція.

Ключові слова: охорона праці, ЗВО, інформаційна технологія забезпечення безпечного виробництва (ІТ ОБП), безпека праці, ІКТ виробництво.

Постановка проблеми. Охорона праці - одна з найбільш гострих проблем сучасного суспільства, що має глобальний характер. Це обумовлено, у першу чергу тим, що до кінця XX - початку XXI ст. різко зросли масштаби промислового виробництва, пов'язані з появою нових технологій і відповідних видів трудової діяльності, збільшенням кількості підприємств тощо. У результаті значною мірою зросла кількість небезпечних виробничих об'єктів, великі промислові аварії на таких об'єктах не тільки призводять до руйнування, припинення виробничої діяльності й загибелі працівників, але і перетворюють величезні території на зони, непридатні або малопридатні для проживання.

Мета дослідження полягає у виокремленні та наведенні основоположних психолого-педагогічних особливостей використання комп'ютерно-орієнтованих систем навчання, зокрема в сфері охорони праці.

Для вирішення та досягнення мети дослідження використано такі методи дослідження:

- теоретичні: теоретичний аналіз філософської, психологопедагогічної, науково-методичної і спеціальної літератури з проблеми дослідження, моделювання педагогічного процесу, узагальнення результатів дослідження з урахуванням конкретних умов і нових фактів; 
- емпіричні: опитування; педагогічні спостереження, самооцінювання;

- методи обробки результатів дослідження: методи математичної статистики для проведення якісного й кількісного аналізу одержаних результатів.

Методологічну основу дослідження склали положення про складну структуру наукового світогляду, що включає філософський, онтологічний, гносеологічний, аксіологічний аспекти; психолого-педагогічні концепції поетапного формування розумових дій і теоретичних узагальнень; роль науки в сучасному суспільстві, закономірності й об'єктивні умови освіти в процесі професійного становлення особистості; психолого-педагогічні наукові теорії і методики в процесі інформатизації освіти та охорони праці.

Аналіз актуальних досліджень. Аналіз наукової літератури дозволяє зробити висновок про те, що окремі психолого-педагогічні і методичні аспекти використання комп'ютерно-орієнтованих систем навчання у педагогічних закладах вищої освіти в процесі фахової підготовки майбутніх фахівців отримали обґрунтоване наукове освітлення в роботах
С. Ф. Аверьянової,
Ю. Н. Афанасьєва,
В. П. Беспалько,
В. Ю. Бикова,
А. Я. Ваграменко,
А. П. Верхоли,
А. Г. Гейна,

Ю. С. Брановського,

Г. С. Гершунського, І. Долінера, М. І. Жалдака, І. М. Зубкової, А. В. Куценко, В.В.Лапінського, Н. Л. Ліпатникової, Л. С. Лісициної, Ю. І. Машбиця, М. Р. Меламуд, С. В .Панюкової, І.Н.Розіної, І.В.Роберт, Р. Г. Семеренко, О. М. Спіріна, О. К. Філатова, В. Ф. Шангіна, С. М. Яшанова та інших.

На основі застосування інформаційних і комп'ютерних інтернеттехнологій Ю.С.Брановський досліджував активізацію навчальної діяльності студентів, В. Ф. Шангін визначив методичні основи пізнавальної діяльності студентів. Роботи вище вказаних авторів стали методологічною основою нашого дослідження.

Виклад основного матеріалу. На сьогодні комп'ютерно-орієнтовані системи навчання знайшли застосування в багатьох сферах діяльності, пов'язаної з апаратним і програмним забезпеченням комп'ютера, зокрема в охороні праці.

Узагальнюючи роботи О. Б. Авраменко (Авраменко, 2013, с. 96), Р. С. Гуревич (Гуревич, 2006, с. 255); М. І. Жалдака (Жалдак, 1983, с. 63), О. М. Спіріна (Спірін, 2005, с. 105) та ін. можна виділити такі завдання, що вирішуються з їх використанням у процесі навчання фахівців у галузі охорони праці:

- підтримка старих ОС з метою забезпечення сумісності з іншими програмними продуктами, апробація нових ОС без збитку для основної системи;

- економія на апаратному забезпеченні при розміщенні декількох моделей серверів на одному реальному сервері; 
- підвищення безпеки ОС, установленої на комп'ютері, шляхом апробації на моделі апаратно-програмних засобів потенційно небезпечного ПЗ або ПЗ невідомого виробника;

- підвищення інформаційної безпеки за рахунок створення моделей апаратно-програмних засобів, обмежених політикою безпеки, наприклад, часом її використання;

- створення необхідних апаратних конфігурацій під час перевірки працездатності додатків у певних умовах (об'єм оперативної пам'яті, дискового простору тощо);

- емуляція апаратних пристроїв, яких немає на комп'ютері (багатоядерних процесорів, жорстких дисків та ін.);

- створення моделі локальної мережі на одному комп'ютері за рахунок одночасного запуску декількох моделей персональних комп'ютерів, об'єднаних у локальну мережу;

- навчання роботі з ОС;

- розробка і тестування ПЗ;

- підвищення мобільності завдяки можливості переміщення й запуску моделі апаратно-програмних засобів на іншому комп'ютері;

- зручне управління моделями відносно створення резервних копій, знімків станів і відновлення працездатності після збоїв.

Таким чином, моделювання апаратно-програмних засобів знаходить застосування в різних сферах діяльності, пов'язаної 3 апаратним і програмним забезпеченням комп'ютера, забезпечуючи заміну реального устаткування його моделями.

Окрім професійної діяльності, моделювання апаратно-програмних засобів сприяє підвищенню ефективності та якості навчання в сфері апаратного і програмного забезпечення комп'ютера за рахунок організації практично зорієнтованого навчання за умови здійснення експериментально-дослідницької діяльності на базі розроблених моделей, забезпечуючи при цьому безпеку функціонування комп'ютерів у разі виникнення перешкод функціонування моделей.

Сформулюємо психолого-педагогічні особливості використання апаратно-програмних засобів комп'ютера в охороні праці:

1. Засвоєння нових знань і оволодівання вміннями працювати 3 програмними засобами, за допомогою яких можуть бути реалізовані інформаційні процеси під час забезпечення безпечного функціонування та охорони праці, а саме, засвоєння знань і оволодіння вміннями працювати: 3 мережевими можливостями ОС, що забезпечують отримання, збір і передачу інформації через локальну мережу браузерами, пошуковими системами Інтернет, що забезпечують збір і пошук необхідної користувачеві інформації з охорони праці; поштовими програмами, що забезпечують отримання, накопичення й передачу інформації; 
можливостями файлової системи, утилітами дефрагментації, очищення диска, архіваторами, що забезпечують зберігання інформації та ін.

2. Розвиток уявлень про моделювання й розширення сфер його використання під час вивчення охорони праці апаратно-програмними засобами комп'ютера.

3. Освоєння і систематизація знань, що відносяться до апаратного забезпечення комп'ютерів: вивчення структури апаратних засобів, окремих апаратних компонентів (процесора, видів пам'яті, зовнішніх налаштувань та ін.) їх налаштування, роботи з драйверами, що сприяють швидкому опануванню основами знань із охорони праці.

4. Оволодівання вміннями працювати з системним і прикладним П3: вивчення різних ОС (інтерфейсу команд установки, налаштування, простого адміністрування ОС); мережевих можливостей ОС (мережевих протоколів, мережевих служб, налаштування підключення до локальної і глобальної мережі, простого адміністрування локальної мережі та ін.); іншого системного програмного забезпечення (утиліт, антивірусних програм, архіваторів та ін.); прикладного ПЗ (при порівнянні різних версій програм, при вивченні програм, розроблених для ОС відмінних від установленої на комп'ютері, під час тестування ПЗ невідомого виробника тощо) у галузі охорони праці.

5. Засвоєння знань і оволодівання вміннями в сфері технологій i засобів захисту інформації в глобальній і локальній мережі від руйнування і несанкціонованого доступу: освоєння методів захисту інформації, програмних засобів індивідуального захисту інформації, віддаленого доступу до комп'ютера та ін.

6. Розвиток навичок порівняння різних апаратно-програмних засобів, виявлення взаємозв'язку апаратного i програмного забезпечення для вирішення завдання їх вибору з охорони праці та безпеки життєдіяльності: порівняння продуктивності апаратно-програмних засобів, що мають різний склад апаратного забезпечення, виявлення необхідного апаратного забезпечення для установки й забезпечення працездатності ПЗ, виявлення можливості роботи з конкретним ПЗ за наявності певного апаратного забезпечення та ін.

На основі складу апаратно-програмного забезпечення виділимо види моделей апаратно-програмних засобів комп'ютера в галузі охорони праці.

1. Модель персонального комп'ютера, не підключеного до інформаційної мережі. Модель створюється на основі визначення; структури, що включає такі обов'язкові елементи: процесор (використовується; процесор комп'ютера, або створюється один або більша кількість процесорів моделі), оперативна пам'ять (визначається розмір оперативної пам'яті, максимальний об'єм якої обмежений вільною 
оперативною пам'яттю комп'ютера), жорсткий диск (створюється жорсткий диск моделі фіксованого розміру, або динамічно розширюваний диск, також до створюваної моделі може бути підключений раніше створений жорсткий диск, максимальний розмір створюваного жорсткого диска моделі обмежується розміром вільного місця на жорсткому диску комп'ютера), ОС, що встановлюється на модель (указується тип ОС, наприклад, Microsoft Windows, Linux, Solaris, та ін., а також визначається конкретна версія встановлюваної OC, наприклад, Windows XP, Windows Vista, Windows 7 або Red Hat Linux, Oracle Linux, ASPLinux та ін.) і інше п3 відповідно до мети моделювання (наприклад, драйвери устаткування, утиліти обслуговування дисків, антивірусні програми, офісні пакети, пакети комп'ютерної графіки, математичні пакети та ін.).

2. Модель персонального комп'ютера, підключеного до мережі Інтернет. Для цієї моделі визначається процесор, оперативна пам'ять, жорсткий диск, установлювана ОС і інше необхідне Пз (наприклад, поштовий клієнт, браузер, брандмауер і інші програмні продукти, що забезпечують безпеку роботи в мережі Інтернет), а також, залежить від вибраного способу підключення комп'ютера до мережі Інтернет, у структуру моделі включається мережева карта, USB порт, або порт СОМ. Виконується підключення моделі до мережі Інтернет на основі використання доданого в структуру моделі апаратного забезпечення і можливостей встановленої ОС.

3. Модель локальної мережі на основі однорангової архітектури. Для розробки цієї моделі аналогічно моделі персонального комп'ютера, не підключеного до інформаційної мережі, створюються моделі персональних комп'ютерів, у структуру кожної з них включається мережева карта, вказується ії тип, що визначає спосіб підключення моделі до локальної мережі: внутрішня мережа (для створення локальної мережі на основі створених моделей комп'ютерів), мережевий міст (для підключення створених моделей у наявну локальну мережу, при цьому кожна з моделей сприйматиметься локальною мережею як окремий комп'ютер), трансляція мережевої адреси пристроїв (для підключення створених моделей у наявну локальну мережу, при цьому локальна мережа сприйматиме модель як комп'ютер, на якому вона функціонує), віртуальний адаптер (для підключення в локальну мережу створеної моделі та комп'ютера); також визначається необхідне Пз (наприклад, брандмауер, поштовий клієнт та ін.). Виконується підключення створених моделей у локальну мережу на основі мережевих можливостей установлених ОС.

4. Модель локальної мережі на основі серверної архітектури. Для розробки цього типу моделей аналогічно моделі персонального комп'ютера, не підключеного до інформаційної мережі, створюються моделі робочих станцій, для кожної з них у структуру включається мережева карта, що визначає спосіб підключення моделі до локальної 
мережі; створюються моделі одного або декількох серверів, для кожної $з$ них визначається встановлювана ОС (наприклад, Windows Server, ASPLinux Server, Novell Open Enterprise Server та ін.), відповідно до мети моделювання визначається склад іншого встановлюваного на сервері ПЗ (наприклад, утиліти обслуговування локальної мережі, сервер баз даних, Web-сервер, проксі-сервер, фаєрвол та ін.), для сервера, як і для робочої станції, у структуру моделі включається мережева карта. Виконується підключення розроблених моделей у локальну мережу на основі мережевих можливостей ОС, установлених на серверах і робочих станціях.

Ґрунтуючись на етапах створення моделей як таких, сформульованих В. Ю. Биковим (Биков, 2008, с. 361), визначимо етапи розробки моделей апаратно-програмних засобів комп'ютера в сфері охорони праці:

1. Визначення мети моделювання. Це перший етап розробки моделі, який зрештою визначає всю подальшу роботу. Оскільки в більшості випадків модель розробляється з метою вивчення апаратних і програмних засобів комп'ютера, мета моделювання може бути сформульована таким чином: розробити структуру, перевірити функціонування автоматизованого робочого місця користувача відповідно до мети його використання, визначити план дій із установки ОС та ін.

2. Аналіз об'єкту моделювання, визначення складу його компонентів (апаратних і програмних засобів). На цьому етапі виконується виділення компонентів апаратно-програмних засобів комп'ютера, до яких належать апаратні засоби (процесор, оперативна пам'ять, жорсткий диск, мережева карта, звукова карта, пристрої введення/виведення інформації та ін.), а також програмні засоби (ОС, драйвери пристроїв, прикладне ПЗ та ін.).

3. Аналіз виділених компонентів, виявлення зв'язків між ними, визначення істотних відповідно до мети моделювання і таких, що підлягають включенню в структуру моделі. На цьому етапі виділяються апаратні компоненти, які мають бути включені в структуру моделі для забезпечення ії функціонування, на основі поставленої мети моделювання виявляється взаємозв'язок апаратного і програмного забезпечення.

4. Вибір виду створюваної моделі. На цьому етапі визначається вид моделі апаратно-програмних засобів, що розробляється: модель персонального комп'ютера, не підключеного до інформаційної мережі; модель персонального комп'ютера, підключеного до мережі Інтернет; модель локальної мережі на основі однорангової архітектури; модель локальної мережі на основі серверної архітектури.

5. Розробка моделі. На цьому етапі вибирається середовище, що забезпечує розробку моделі апаратно-програмних засобів з визначеної на 3-у кроці розробки моделі структурою.

6. Перевірка функціонування моделі: Після закінчення розробки моделі тестується функціонування моделі: перевіряється працездатність 
апаратного і програмного забезпечення, коректність підключення до локальної мережі й мережі Інтернет, якщо таке передбачалося та ін.

7. Аналіз адекватності побудованої моделі об'єкту й меті моделювання: На цьому кроці перевіряється відтворення моделлю 3 необхідною повнотою всіх характеристик об'єкту моделювання, істотних відповідно до мети моделювання.

Виділимо завдання зі сфери апаратного та програмного забезпечення, вирішення яких можливе 3 використанням моделі персонального комп'ютера, не підключеного до інформаційної мережі:

- вивчення основних компонентів апаратно-програмного забезпечення персонального комп'ютера: процесора, видів пам'яті, пристроїв введення/виведення тощо;

- організація тестування потенційно-небезпечного ПЗ або ПЗ невідомого виробника за рахунок його ізоляції на створеній моделі;

- організація вивчення установки, налаштування, тестування П3, що не вимагає реєстрації в мережі Інтернет.

Перерахуємо завдання зі сфери апаратного та програмного забезпечення, рішення яких можливе 3 використанням моделі персонального комп'ютера, підключеного до мережі Інтернет:

- вивчення способів підключення до мережі Інтернет;

- вивчення й налаштування програм, що забезпечують роботу користувача із сервісами Інтернету, наприклад, програм електронної пошти і браузерів;

- вивчення інформаційних процесів отримання, пошуку, зберігання й поширення інформації через мережу Інтернет;

- вивчення роботи протоколів мережі Інтернет.

Розглянемо завдання 3 області апаратного та програмного забезпечення, рішення яких можливе з використанням моделі локальної мережі на основі однорангової архітектури:

- вивчення мережевих можливостей ОС, установлених на персональних комп'ютерах;

- вивчення адресації в локальних мережах, працюючих на основі однорангової архітектури;

- вивчення простого адміністрування однорангової локальної мережі;

- вивчення інформаційних процесів пошуку, передачі, зберігання й поширення інформації через однорангову локальну мережу;

- вивчення роботи мережевих протоколів;

Перерахуємо завдання 3 області апаратного та програмного забезпечення, вирішення яких можливе з використанням моделі локальної мережі на основі серверної архітектури:

- вивчення мережевих ОС, що установлюються на серверах; 
- вивчення адресації в локальних мережах, що працюють на основі серверної архітектури;

- вивчення простого адміністрування локальної мережі на основі серверної архітектури;

- вивчення інформаційних процесів пошуку, передачі, зберігання і поширення інформації через локальну мережу на основі архітектури;

- вивчення, установка, налаштування і тестування роботи серверних програм, наприклад, сервера баз даних, проксі-сервера;

Перейдемо до розгляду переваг використання моделей апаратнопрограмних засобів під час організації навчання в сфері охорони праці в порівнянні з його вивченням безпосередньо на реальному комп'ютері:

1. Оскільки робота виконується не на комп'ютері, а на моделі, фахівці з питань охорони праці можуть здійснювати експериментальнодослідну діяльність зі зміни складу апаратного забезпечення, установки, налаштування й тестування ПЗ в умовах забезпечення безпечної роботи комп'ютера й інформаційної мережі освітньої установи при можливих помилкових діях або дії комп'ютерних вірусів та інших шкідливих програм, що викликають збій функціонування моделей.

2. Стан моделі апаратно-програмного засобу може бути збережений у будь-який момент часу, що дає можливість перервати експеримент і відновити його з того самого місця (а не з початку) в наступний сеанс роботи.

3. Можливість збереження стану моделі й повернення до збереженого стану дозволяє швидко відмовитися від невірних дій, що викликали проблеми функціонування моделі та знову повторити експеримент.

4. Створена модель зберігається в окремих файлах, що дає можливість легко перенести модель на інший комп'ютер і запустити їі там, унаслідок чого немає «жорсткої прив'язки» до конкретного комп'ютера.

5. Викладач може підготувати модель для проведення необхідного експерименту для студентів (наприклад, для виявлення та виправлення невірних дій зі збирання та налаштування до роботи ручних засобів пожежогасіння.

6. На модельований комп'ютер може бути встановлена ОС, відмінна від тієї, яка функціонує на комп'ютері. Це дає можливість одночасного запуску, двох або більшої кількості ОС для їх порівняльної характеристики та зручності в роботі.

7. На модельованому комп'ютері можуть бути встановлені версії прикладного ПО відмінні від установлених на комп'ютері, що дає можливість порівняльної характеристики різних версій.

8. Використання моделей підвищує безпеку функціонування комп'ютера за рахунок тестування на моделі потенційно небезпечного Пз.

9. Для перевірки працездатності ПЗ в заданих умовах (за необхідного об'єму оперативної пам'яті, розміру жорсткого диска, установленої ОС та 
ін.) розробляється модель, що має відповідні апаратні та програмні компоненти.

10. Завдяки одночасному запуску декількох моделей, об'єднаних у локальну мережу, організовується вивчення локальної мережі на одному реальному комп'ютері.

11. Під час комплектації автоматизованого робочого місця відповідно до цілей його використання студент одночасно може мати декілька різних моделей із різною комплектацією, наприклад, модель комп'ютера викладача, інженера, фахівця з охорони праці та ін.

у деяких випадках для забезпечення практичної спрямованості навчання в сфері охорони праці розробляються інтерактивні презентації, що дозволяють студентам виконувати окремі налаштування апаратних і/або програмних засобів. Ми вважаємо, що порівняно з вивченням охорони праці за допомогою інтерактивних презентацій використання моделей апаратно-програмних засобів має низка переваг:

1. У презентації процес налаштування апаратного i/або програмного забезпечення закінчується повідомленням про «вірне» або «невірне» ії виконання, під час роботи з моделлю - функціонуванням моделі, що підвищує наочність результатів роботи.

2. Презентація дає можливість виконати обмежену кількість налаштувань, модель - будь-які зміни і налаштування.

3. Зміна версій ПЗ тягне необхідність корекції презентації, що $\epsilon$ трудомістким і довгим процесом, робота з моделлю - звичайної установки нової версії ПЗ.

Висновки та перспективи подальших наукових розвідок. Принципово, що під час використання комп'ютерних навчальних програм задіює не тільки сферу професійних знань працівника, але й задіюється емоційна сфера. Фото і відеофрагменти 3 місць подій (аварія на залізничному переїзді, падіння автокрана, безвихідність для безлічі людей при пожежі, репортаж із лікарні про постраждалих від нещасного випадку, результати аварії під час роботи навантажувача і тому подібне), залишають помітніший слід у пам'яті, чим словесний опис. Це важливо, оскільки передумовою нещасних випадків часто $€$ навіть не відсутність потрібних знань, а елементарна втрата відчуття загрози.

Охорона праці - проблема складна й багатогранна. У сучасній науці особливо підкреслюється багатоаспектність феномену охорони праці, який сприймається водночас як соціальне та економічне явище, яке важливе для забезпечення гармонійного розвитку кожного працівника, процвітання суспільства і держави в цілому.

Щодо перспектив подальших розвідок у даному напрямку, то наукового вирішення потребують питання змісту та введення в обов'язковий цикл дисциплін навчального плану дисципліни «Безпека 
життєдіяльності», а також інформаційного, методичного, матеріальнотехнічного забезпечення навчального процесу викладання дисципліни «Охорона праці» в у ЗВО.

\section{ЛІТЕРАТУРА}

Авраменко, О.Б. (2013). Науково-методичне забезпечення дистанційного навчання інформатичних дисциплін майбутніх учителів технологій (матеріали конференції). Умань (Avramenko, О.В. (2013). Scientific and methodological support of distance learning of information disciplines of future technology teachers (conference materials). Uman).

Биков, В. Ю. (2008). Інформатизація освіти (Енциклопедія освіти). Київ (Bykov, V. Yu. (2008). Informatization of Education (Encyclopedia of Education). Kyiv).

Гуревич, Р.С. (2006). Інформаційно-телекомунікаційні технології в навчальному процесі та наукових дослідженнях (навч. посібник). Київ (Hurevych, R. S. (2006). Information and telecommunication technologies in the educational process and scientific research (textbook). Kyiv).

Жалдак, М.І. (1983). Гуманітарний потенціал і інформатизація освіти (навч. посібник). Київ (Zhaldak, М. І. (1983). Humanitarian potential and informatization of education (textbook). Kyiv).

Спірін, О.М. (2005). Методологічні засади розвитку сучасних систем вищої освіти. Вісник Житомирського державного університету імені Івана Франка, 20, 104109 (Spirin, O. M. (2005). Methodological foundations for the development of modern higher education systems. Bulletin of Zhytomyr Ivan Franko State University, 20, 104-109).

\section{PEЗЮME}

Шевченко Владимир. Психолого-педагогические особенности использования компьютерно-ориентированных систем обучения охране труда.

Сегодня большинство образовательных учреждений сталкиваются с организационными, техническими и материальными трудностями при организации обучения в области аппаратного и программного обеспечения компьютера на реальном оборудовании с установленным на нем программным обеспечением (ПО), экспериментирование $c$ которым может привести к сбоям или временного прекращения функционирования оборудования.

Часто при проведении практического занятия нет возможности выделить студентам компьютеры для изучения аппаратных средств, установки настройки и тестирования ПО конкретной группой студентов; в большинстве случаев при установке и настройке ПО требуется наличие полномочий администратора, не предоставляются студентам, исходя из необходимости обеспечения безопасности компьютеров и информационной сети образовательного учреждения.

Ключевые слова: охрана труда, ЗВО, информационная технология обеспечение безопасного производства (ИТ ОБТ), безопасность труда, ИКТ производство.

\section{SUM MARY}

Shevchenko Volodymyr. Psychological and pedagogical features of the use of computer-oriented systems of training occupational safety.

Regulation of work safety and protection of workers' health always occupies an important place in all sectors, especially in education. These tasks are an integral part of the overall management system of the institution, organization or educational institution, as well as they provide risk control in the field of health protection and employment of all workers. 
In terms of socio-economic transformation of society, modernization of secondary and higher pedagogical schools, special importance of a critical rethinking of the whole experience, in-depth analysis of practice training of teachers of technologies, it is necessary to define what experience should be preserved and what should be changed or updated under the influence of new tendencies and processes occurring in society. Updating the content of education is one of the problems of the modern educational industry.

The content of education should embody realization of the social order, that is, the need of society to transfer social experience to the younger generation, which is one of the factors of economic and social progress of society. The younger generation should be focused on ensuring self-determination of the individual, creating conditions for its self-realization; on the development of civil society; on strengthening and improving the rule of law. The content of education in a particular education institution is determined by the educational program, which is developed, adopted and implemented by this education institution independently. Providing the educational process with normative intra-University documents becomes an effective tool for personnel training management and, consequently, continuous improvement of this process in the event that it is systemic and covers all aspects of the learning and education processes.

Today, most education institutions face organizational, technical, financial difficulties in organizing training in the field of computer hardware and software on real hardware with software installed on it, experimenting with which may result in malfunctions or temporary suspension of the equipment. Often, during the practical training, it is not possible to allocate computers to students to study hardware, set up customization and test software for a specific group of students; in most cases, installing and configuring software requires administrator privileges that are not provided to students, based on the need to ensure the security of computers and the educational network; some software installation and setup took a long time to complete.

Key words occupational safety, occupational health and safety management system, civil protection, professional training, informatization, integration, competences.

Кристина Шевчук

Чернівецький національний університет імені Юрія Федоровича ORCID ID 0000-0002-9365-1456

Ганна Бигар

Чернівецький національний університет імені Юрія Федоровича ORCID ID 0000-0001-8373-463X

Аліна Предик

Чернівецький національний університет імені Юрія Федоровича ORCID ID 0000-0001-7356-8690

DOI 10.24139/2312-5993/2020.02/215-224

\section{ОСОБЛИВОСТІ ПІДГОТОВКИ МАЙБУТНІХ УЧИТЕЛІВ ПОЧАТКОВИХ КЛАСІВ ДО ОРГАНІЗАЦІї КРАЄЗНАВЧОЇ РОБОТИ}

Стаття присвячена актуальній проблемі сучасної педагогічної парадигми підготовці майбутніх учителів початкових класів до організачії краєзнавчої роботи. Актуальність даної проблеми в науковому обігу зумовлено введенням нових освітніх стандартів, які визначають пріоритетні завдання, що передбачають модернізацію змісту і методів підготовки майбутнього вчителя шляхом повної реалізації його потенційних можливостей. Акцентовано увагу на створенні й функціонуванні в структурі початкової освіти особливої системи знань про культурно-історичні 